\title{
CHARACTERIZATION OF INDIGENOUS YEASTS SPECIES ISOLATED FROM FRUITS FOR PINEAPPLE WINE PRODUCTION
}

\author{
Fadahunsi Ilesanmi Festus $^{1 凶}$, Akoja Abiodun David ${ }^{1}$, Ozabor Temilade Praise ${ }^{1}$ \\ ${ }^{1}$ Department of Microbiology University of Ibadan, Ibadan Nigeria \\ ${ }^{\square}$ Sanmifadahunsi@yahoo.com \\ https://doi.org/10.34302/crpjfst/2020.12.5.8 \\ Article history: \\ Received: \\ 28 August 2020 \\ Accepted: \\ 25 December 2020

\section{Keywords:} \\ Characterization, \\ Yeast species, \\ Fruits, \\ Starter cultures, \\ Pineapple wine.

\begin{abstract}
This study was designed to characterize yeast species isolated from fruits and use as starter cultures in pineapple wine production. Forty yeast isolates were obtained from fermenting pineapple, watermelon and cashew juices using culture-dependent method and screened for pathogenicity properties. Eleven of the yeast isolates were non-pathogenic and were investigated for their abilities to produce invertase, tolerate ethanol, sugars, grow at different temperatures and $\mathrm{pH}$ by spectrophotometric method. Identification of the yeast isolates was carried out using API (ID 32C) kit. The result obtained showed that Isolate PIN32 (Saccharomyces cerevisiae 4) had the highest invertase activity of $40.04 \pm 0.5 \mathrm{Umol} / \mathrm{min}$ followed by $30.17 \pm 0.1 \mathrm{Umol} / \mathrm{min}$ produced by WAM8 (Saccharomyces cerevisiae 1). The highest tolerance to ethanol was demonstrated by isolate PIN32 (Saccharomyces cerevisiae 4) and WAM8 (Saccharomyces cerevisiae1) with a growth of $1.31 \pm 0.3$ and $1.26 \pm 0.2$ respectively. Optimum glucose tolerance was observed in WAM8 (Saccharomyces cerevisiae1), while PIN32 (Saccharomyces cerevisiae 4) demonstrated the highest growth in $20 \%$ sucrose. Similarly PIN32 (Saccharomyces cerevisiae 4) and WAM8 (Saccharomyces cerevisiae 1) recorded the highest growth of 1.55 at $\mathrm{pH} 6$. All isolates exhibited optimum growths at $30^{\circ} \mathrm{C}$ with PIN32 recording the highest growth. The isolates were identified as Saccharomyces cerevisiae, Pichia farinosa, Saccharomyces kluyveri, Kloeckera japonica, Pichia ohmeri, Debaromyces polymorphus, Candida kefyr. The result showed that PIN32 and WAM 8 could be selected as potential starter cultures for pineapple wine production based on the empirical findings in this work.
\end{abstract}

\section{Introduction}

Yeasts are eukaryotic microorganisms and they are widely encountered in ecological niches such as fruits, grains, soil and fermented food but they are mostly isolated from citrus juices and sugar cane (Tamang,2016) They are important in many complex ecosystems, as frequent early colonizers of nutrient rich substrates (Djelal et al.2017). Saccharomyces cerevisiae (baker's and brewer's yeast) is the most studied species because it utilizes hexose sugar to produce $\mathrm{CO}_{2}$, ethanol, and variety of secondary metabolites such as esters, aldehyde and amino acids that contribute to the development of flavour and aroma of fermented foods (Pretotoritus, 2000). Unlike bacteria, yeasts are osmophilic and can grow in media of low water activities and acid pH. (Deak, 2006).) These biotechnological properties exhibited by saccharomyces cerevisiae have made them suitable in the production of wine of good quality and consumers acceptability(Turker, 2014).However Yeast metabolism and physiology are thus strongly dependent on sugar and oxygen Unlike bacteria, yeasts are osmophilic and can grow in media of low water activities and acid pH.(Dickinson and Kruckeberg, 2006)..Its enhanced applications in 
alcoholic fermentation, bread-making, single cell protein, vitamin production, synthesis of recombinant proteins, and biological control is well documented (Akabanda et al.,. 2013).Its high tolerance to sugar, ethanol, high temperature are the biotechnological properties leading to its selection for alcoholic fermentation (Islam et.al.,2015)

These biotechnological properties exhibited by saccharomyces cerevisiae have made them suitable in the production of wine of good quality and consumers acceptability (Turker, 2014).

Wine is a fermented beverage prepared from fresh fruit juices by normal alcoholic fermentation (Okafor,2007). In wine production ,yeast ferments the hexose sugar present in the substrate a process named alcoholic fermentation to ethanol, carbon dioxide and other secondary metabolites.(Robinson,2006) The quality of wine depends largely on the yeast strain used (Idise, 2012). Wines produced from grape (Vitis species) are called the true wines while wines from other fruits are referred to as fruit wines and they are named using the name of the fruit used for their production e.g., orange wine, banana wine, cherry wine and pineapple wine (Lea et al., 2003). It is reported that wine and other alcoholic drinks are used in entertaining guests during conferences, rallies, marriage, christening, and burial ceremonies.. This has made it an integral part of the Nigerian society and many people believe strongly in its ability to prevent cardiovascular disease because of its high content of polyphenol such resveratrol, anthocyanin and catechins (Snopek et al.,2018). Most of the common fruits being utilized for wine and juice making are cashew, pineapple, mango and orange. Fruits supplement the quality of our diet by providing essential ingredients like vitamins, minerals, carbohydrates. They are seasonal products and are available in large quantity during their harvesting period but a higher percentage is wasted due to lack of available storage facilities and underutilization. This wastage can be arrested by processing and conversion of these fruits into other useful valued products which will make them available all year round. Such possible products are wines, concentrate and confectionaries (Bolarin et al., 2016).

Pineapple (Ananas comosus)belongs to the Bromeliaceae family and is planted in different regions of Nigeria either for export or for the local consumption. It can be eaten fresh or process into fruit juices or concentrates for future use. Nutritionally it contains $81.2-86.2 \%$ moisture, $13-19 \%$ total solids of which sucrose, glucose, and fructose are the main components with 2-3\% fiber, a high level of vitamin $\mathrm{C}$ and calcium (Sun et al.,2016). It is also reported to possess proteolytic activity due to the presence of bromelin couple with low amount of lipids and nitrogenous compounds (Shetty et al.,2019)The pineapple varieties commonly grown in Africa have sufficient sugar levels and favorable $\mathrm{pH}$ (4.5-6.5) for fermentation to occur (Idise, 2012). Thus, through fermentation the highly perishable pineapple fruit could be converted into a highly nutritious wine which can be made available all year round (Keller, 2010). In Nigeria, $50 \%$ of the pineapple harvested annually is wasted due to lack of adequate storage facility. It is therefore suggested that government and private investors should look inwards as to developing wineries that will exploit optimally the utilization of this fruit, considering the fact that a huge amount of foreign exchange and employment will be derived from the exportation of wine (Akubo, et al., 2003).

In this present work, attempt was made to characterize indigenous yeast species isolated from fruits to select potential starters for pineapple wine production with the aim of developing wine with long shelf life, desirable sensory attributes coupled with improved nutritional quality and consumer's acceptability.

\section{Materials and methods}

\subsection{Materials}

\subsubsection{Samples}

Samples of pineapple, water melon and cashew nut were collected from Military Cantonment Oshodi in Lagos and Bodija market in Ibadan, Nigeria in sterile ethylene bags and 
transported to the Food and Applied Microbiology laboratory, Department of Microbiology University of Ibadan, Nigeria.

\subsection{Methods}

2.2.1. Treatment of sample and isolation procedure

The barks of the pineapple, water melon and cashew fruits were removed and cut into pieces using a sharp knife. They were allowed to ferment naturally for three days and their juices were extracted using a juice extractor machine. The juices were serially diluted with one $\mathrm{ml}$ from dilutions $10^{-4}$ and $10^{-5}$ was inoculated into sterile Petri dishes containing malt extract agar and incubated at $30^{\circ} \mathrm{C}$ for three days. The Petri dishes were observed for microbial growth and representative colonies sub-cultured repeatedly to obtain pure cultures which were maintained on malt extract agar slant at $4^{\circ} \mathrm{C}$.

2.2.2. Pathogenicity Test

2.2.2.1.Gelatin Liquefaction:

The method described by dele-Cruz and Torres (2012) was used. One $\mathrm{ml}$ from a $24 \mathrm{~h}$ old culture of the yeast cells suspension was inoculated into sterile gelatin medium in $50 \mathrm{~mL}$ Erlenmeyer flasks containing $10 \%$ malt extract and incubated at $30^{\circ} \mathrm{C}$ for 7 days. The temperature was reduced to observe liquefaction. At lower temperature, liquefaction of gelatin indicates positive reaction while unliquefied gelatin indicates negative reaction.

\subsubsection{Hemolysis test}

This was carried out by streaking a colony from a $24 \mathrm{~h}$ old culture of the yeast cells on blood agar plates and incubated for 24-72h at $30^{\circ} \mathrm{C}$. The plates were observed for alpha, beta or gamma hemolytic reaction (Akinjogunla et.al. 2014).

\subsubsection{DNase test}

The method described by Akinjogunla et. al.. (2014). was adopted by picking a colony from a $24 \mathrm{~h}$ old culture of yeast cells and streaked on DNase agar plates containing methyl green indicator and incubated at $37^{\circ} \mathrm{C}$ for $72 \mathrm{~h}$. The plate was observed for green color fades surrounded by a colorless zone.

\subsection{Identification procedure}

Identification of the isolates was carried out by considering their macroscopic and microscopic characteristics (Tika et al.(2017) and by employing the API (ID 32C) test kit.

\subsection{Determination of invertase production.}

Determination of invertase production was carried out by inoculating $1 \mathrm{ml}$ from a $24 \mathrm{~h}$ old culture of yeast cells suspension into sucrose $(4 \% \mathrm{w} / \mathrm{v}, 2 \mathrm{ml})$ in $10 \mathrm{ml}$ solution of acetate buffer( $\mathrm{pH} 5$ ) and incubated for $5 \mathrm{~min}$ at $30^{\circ} \mathrm{C}$. The amount of reducing sugar released was determined by dinitro-salicylic acid method Tika et al.(2017).The amount of enzyme which liberate $1 \mu$ mole reducing sugar per minute was defined as one unit of Invertase activity.

\subsection{Determination of ethanol tolerance}

This was carried out by inoculating $0.1 \mathrm{ml}$ from a $24 \mathrm{~h}$ old culture of yeast cells suspension into $10 \mathrm{ml}$ sterile malt extract broth containing different concentrations of ethanol $(0,5,10,15$ and $20 \%$ ) The tubes were incubated at $30^{\circ} \mathrm{C}$ for $48 \mathrm{~h}$. and the initial optical densities were read from an UV spectrophotometer (Pharamacia LK13Ultraspec II) set at $560 \mathrm{~nm}$. The tubes were transferred into a gyratory shaker incubator set at $150 \mathrm{rpm}$ at $30^{\circ} \mathrm{C}$ for $24 \mathrm{~h}$ and the final optical density was read.

\subsection{Determination of sugar tolerance}

The modified method described by Shankar et. al.(2013) was used by inoculating $0.1 \mathrm{ml}$ from a $24 \mathrm{~h}$ old culture of the yeast cells suspension into sterile malt extract broth in several $100 \mathrm{ml}$ Erlenmeyer flasks containing $10 \%, 20,3 \%$ and $40 \%$ ) glucose concentrations and incubation was carried outat $30^{\circ} \mathrm{C}$ for $72 \mathrm{~h}$. Growth was determined using an UV visible spectrophotometer (Pharamacia LK13Ultraspec II) set at $560 \mathrm{~nm}$. The experiment was repeated by replacing glucose with sucrose.

\subsection{Determination of growth at different $\mathrm{pH}$}

$1 \mathrm{ml}$ from a $24 \mathrm{~h}$ old culture of the yeast cells suspension was into several sterile malt extract broth in $100 \mathrm{ml}$ Erlenmeyer flasks with $\mathrm{pH}$ 
adjusted to 2, 4, 6 and 8 and incubated at $30^{\circ} \mathrm{C}$ for $72 \mathrm{~h} \mathrm{~h}$ and growth was determined using an UV visible spectrophotometer (Pharamacia LK13Ultraspec II) set at 560nm.

\subsection{Determination of growth at different temperatures}

One $\mathrm{ml}$ from a $24 \mathrm{~h}$ old culture of the yeast cells suspension was inoculated into sterile malt extract broth in several $100 \mathrm{ml}$ Erlenmeyer flasks with $\mathrm{pH}$ adjusted to 6 . Incubation was carried out at different temperatures $(20,25,30,35,40$ and 45 ) for $72 \mathrm{~h}$ and growth was determined by using an UV visible spectrophotometer ( Pharamacia LK13Ultraspec II) set at 560nm.
All experiments reported in this study were carried out in triplicates

Statistical analysis

Descriptive statistical method in statistical package for social science (SPSS version17) was used for data analysis to determine means and standard errors.

\section{Results and discussions}

The screening for pathogenic properties of the yeast isolates is shown in Table 1. It was observed that the eleven isolates tested were negative to gelatin liquefaction, heamolysis and DNase production.

Table 1. Pathogenicity test of yeast isolates

\begin{tabular}{|c|l|l|l|}
\hline Isolate Code & Gelatin Liquefaction & Haemolytic Test & Dnase Test \\
\hline WAM 8 & & - & \\
\hline WAM 11 & - & - & \\
\hline WAM 20 & & & \\
\hline WAM 25 & & - & \\
\hline PIN 10 & & & \\
\hline PIN 40 & & & \\
\hline PIN 32 & & - & \\
\hline PIN 12 & & & \\
\hline CAS 15 & & - & \\
\hline CAS 36 & - & - & - \\
\hline CAS 3 & - & - & \\
\hline
\end{tabular}

Key - WAM-8:Saccharomyces cerevisiae 1,WAM-11:Pichia farinosa,WAM-20: Saccharomyces cerevisiae2,WAM25:Kloeckera japonica; PIN-10:Saccharomyces kluyveri, PIN-40: Saccharomyces cerevisiae3,PIN-32: Saccharomyces cerevisiae 4, PIN-12:Saccharomyces cerevisiae 5 CAS-15: Pichia ohmeri;CAS-36:Debaryomyces polymorphus;CAS-3: Candida kefyr.

The result of Invertase production by the yeast isolates is presented in Table 2.

All the yeast isolates produced varying amounts of invertase with Isolate PIN32(Saccharomyces cerevisiae 4) showing the highest invertase activity of $40.04 \pm 0.5 \mathrm{Umol} / \mathrm{min}$ followed by an activity of $30.17 \pm 0.1 \mathrm{Umol} / \mathrm{min}$ produced by WAM 8 (Saccharomyces cerevisiae 1) and the least activity of $13.87 \pm 0.2 \mathrm{Umol} / \mathrm{min}$ was recorded in CAS36 (Debaromyces polymorphus).

The observed result in the screening of yeast for pathogenicity properties is in conformity with the findings of Eze et al.(2011). He previously reported that yeast isolates are not gelatinase producers and the absence of gelatinase, haemolysis and dnase production by these micro-organisms accord them acceptability in the food industry as starter cultures. 
Table 2. Invertase production by the yeast isolates

\begin{tabular}{|c|c|}
\hline Isolate number & $\begin{array}{c}\text { Invertase activity } \\
\text { Umol/min }\end{array}$ \\
\hline WAM 8 & $30.17 \pm 0.1$ \\
\hline WAM 11 & $18.85 \pm 0.1$ \\
\hline WAM 20 & $25.64 \pm 0.2$ \\
\hline WAM 25 & $20.51 \pm 0.4$ \\
\hline PIN 10 & $28.82 \pm 0.3$ \\
\hline PIN 40 & $26.28 \pm 0$. \\
\hline PIN 32 & $40.04 \pm 0.5$ \\
\hline PIN12 & $14.66 \pm 0.9$ \\
\hline CAS 15 & $20.03 \pm 0.7$ \\
\hline CAS36 & $13.87 \pm 0.2$ \\
\hline CAS3 & $18.27 \pm 0.2$ \\
\hline
\end{tabular}

Production of invertase by a wide range of microorganisms such as Saccharomyces cerevisiae and S.carlsbergensis had been earlier reported (Sivakumar et al.; 2013) Mahesh et al.(2012) reported that $S$. cerevisiae possesses a great ability to secrete invertase while Talekar et al. (2010) confirmed that this enzyme is highly significant in the cleavage of $\alpha-1,4$ glycosidic linkage between $\alpha$-D-glucose and $\beta$-D-fructose molecules of sucrose by hydrolysis and releases monosaccharide. In addition, Guimaraes et al. (2007) described the general use of invertase in the production of confectionary with liquid or soft center invert syrup, calf feed preparation, pharmaceutical, food and fermentation of cane molasses into ethanol. The tolerance of the yeasts isolates to different concentration of ethanol is shown in Table 3. The result showed that all the yeasts isolates tolerated the different concentrations $(5 \%-15 \%)$ of ethanol used producing different levels of growth with the highest recorded at lower concentration of ethanol. The highest tolerance to ethanol was demonstrated by Isolate PIN32 (Saccharomyces cerevisiae 4) by producing a growth of $1.31 \pm 0.3$ (optical density) followed by a growth of $1.26 \pm 0.2$ recorded by WAM8 (Saccharomyces cerevisiae1) while the least growth of $0.72 \pm 0.3$ was seen in CAS3 (Candida kefyr) at 15\% ethanol.

Table 3. Tolerance of yeast isolates to different ethanol concentrations

\begin{tabular}{|l|l|l|l|l|}
\hline Isolate code & $\mathbf{5 \%} / \mathbf{v}$ & $\mathbf{1 0 \%} / \mathbf{v}$ & $\mathbf{1 5 \%} / \mathbf{v}$ & $\mathbf{2 0 \%} / \mathbf{v}$ \\
\hline WAM8 & $1.74 \pm 0.5$ & $1.54 \pm 0.5$ & $1.26 \pm 0.2$ & $0.00 \pm 0.0$ \\
\hline WAM11 & $1.37 \pm 0.9$ & $1.15 \pm 0.2$ & $1.00 \pm 0.3$ & $0.00 \pm 0.0$ \\
\hline WAM20 & $1.61 \pm 0.1$ & $1.37 \pm 0.0$ & $1.21 \pm 0.6$ & $0.00 \pm 0.0$ \\
\hline WAM25 & $1.44 \pm 0.0$ & $1.18 \pm 0.9$ & $1.02 \pm 0.4$ & $0.00 \pm 0.0$ \\
\hline PIN10 & $1.25 \pm 0.3$ & $1.14 \pm 0.8$ & $0.90 \pm 0.0$ & $0.00 \pm 0.0$ \\
\hline PIN40 & $1.54 \pm 0.3$ & $1.37 \pm 0.2$ & $1.11 \pm 0.1$ & $0.00 \pm 0.0$ \\
\hline PIN32 & $1.83 \pm 0.1$ & $1.58 \pm 0.3$ & $1.31 \pm 0.3$ & $0.00 \pm 0.0$ \\
\hline PIN12 & $1.47 \pm 0.8$ & $1.04 \pm 0.7$ & $0.76 \pm 0.0$ & $0.00 \pm 0.0$ \\
\hline CAS15 & $1.44 \pm 0.2$ & $1.05 \pm 0.6$ & $0.80 \pm 0.0$ & $0.00 \pm 0.0$ \\
\hline CAS36 & $1.33 \pm 0.6$ & $1.06 \pm 0.4$ & $0.81 \pm 0.1$ & $0.00 \pm 0.0$ \\
\hline CAS3 & $1.37 \pm 0.0$ & $1.05 \pm 0.1$ & $0.72 \pm 0.2$ & $0.00 \pm 0.0$ \\
\hline
\end{tabular}

The ethanol tolerance of yeast isolates seen in this present work is observed to be species dependent. The yeast species were able to grow in different concentrations of ethanol due to the 
ability of their cell wall to withstand osmotic stress (plasmolysis) (Gomar-Alba et al.2015). This observation had earlier been reported by Dash et al. (2015); Alloysius et al. (2015). However, Osho (2005) reported that the alcoholic tolerance for most brewing yeast strains was within $9-10 \%$ ethanol concentration. Studies have shown that ethanol tolerant yeasts are also sugar-tolerant (Balakmar and Arasatnam,, 2012; Techaparin et al.,.2017) and the combination of the two properties are important in the selection of yeast species for industrial application especially in fermentative production of ethanol, wine, alcoholic beverages and baking products (Moneke et al., 2008; Patruscus et al.,2009). Ethanol tolerance is a crucial characteristic of microorganisms involved in the production of alcohol because the process will be inhibited if the fermenting microorganism could not tolerate the alcohol produced (Thammasttirong et al.,2013).
(Thammasttirong et al.,.2013) Albergaria and Arneborg (2016);Alonso del-real et al.(2017) explained that the ability of yeast spp. to survive in high alcoholic wine is an indication of their high ethanol tolerance and this characteristics is used in the selection of yeast spp. for industrial ethanol production (Chandasena et al., 2006; Patruscus et al.,.2009).

Table 4 shows the result of tolerance of yeast isolates to different glucose concentration. All the isolates had maximum growth at $20 \%$ glucose but at higher concentration growth decreased. In addition, the highest glucose tolerance was observed in WAM8 (Saccharomyces cerevisiael) recording a growth of $2.46 \pm 0.1$ followed by PIN32 (Saccharomyces cerevisiae 4) with a growth of $2.34 \pm 0.1$ and the least was observed in WAM25 (Kloeckera japonica) with a growth of $2.04 \pm 03$ in $20 \%$ glucose.

Table 4. Tolerance of yeasts isolates to different glucose concentration

\begin{tabular}{|c|c|c|c|c|}
\hline Isolates & $\mathbf{1 0 \%}$ & $\mathbf{2 0} \%$ & $\mathbf{3 0 \%}$ & $\mathbf{4 0 \%}$ \\
\hline WAM8 & $2.11 \pm 0.8$ & $2.46 \pm 0.1$ & $2.25 \pm 0.5$ & $2.16 \pm 0.1$ \\
\hline WAM11 & $2.07 \pm 0.6$ & $2.20 \pm 0.0$ & $2.10 \pm 0.6$ & $2.05 \pm 0.0$ \\
\hline WAM20 & $2.07 \pm 0.6$ & $2.06 \pm 0.3$ & $2.00 \pm 0.0$ & $1.90 \pm 0.5$ \\
\hline WAM25 & $2.01 \pm 0.6$ & $2.04 \pm 0.3$ & $1.99 \pm 0.1$ & $1.83 \pm 0.9$ \\
\hline PIN10 & $2.03 \pm 0.0$ & $2.06 \pm 0.2$ & $1.91 \pm 0.2$ & $1.80 \pm 0.3$ \\
\hline PIN40 & $2.01 \pm 0.1$ & $2.09 \pm 0.5$ & $1.81 \pm 0.1$ & $1.72 \pm 0.4$ \\
\hline PIN32 & $2.09 \pm 0.1$ & $2.34 \pm 0.1$ & $2 . .20 \pm 0.8$ & $2.10 \pm 0.4$ \\
\hline PIN12 & $2.01 \pm 0.2$ & $2.18 \pm 0.7$ & $2.10 \pm 0.0$ & $1.88 \pm 0.2$ \\
\hline CAS15 & $2.07 \pm 0.5$ & $2.20 \pm 0.0$ & $2.00 \pm 0.9$ & $1.90 \pm 0.6$ \\
\hline CAS36 & $2.06 \pm 0.7$ & $2.18 \pm 0.6$ & $2.01 \pm 0.3$ & $1.70 \pm 0.7$ \\
\hline CAS3 & $2.02 \pm 0.3$ & $2.07 \pm 0.8$ & $1.99 \pm 0.1$ & $1.72 \pm 0.0$ \\
\hline
\end{tabular}

The result of tolerance of the yeast isolates to different sucrose concentration is presented in Table 5. It was observed that PIN 32 (Saccharomyces cerevisiae 4) recorded the highest growth of $2.39 \pm 0.1$ followed by a growth of $2.30 \pm 0.3$ produced by WAM8 (Saccharomyces cerevisiae1) while the least growth of $2.10 \pm 0.0$ recorded by WAM11 (Pichia farinosa) in $20 \%$ sucrose.

Table 5. Tolerance of yeasts isolates to different sucrose concentration

\begin{tabular}{|l|c|c|c|c|}
\hline Isolate code & $10 \%$ & $20 \%$ & $30 \%$ & $40 \%$ \\
\hline WAM8 & $2.20 \pm 0.3$ & $2.30 \pm 0.3$ & $1.83 \pm 0.1$ & $1.01 \pm 0.7$ \\
\hline WAM11 & $2.02 \pm 0.6$ & $2.10 \pm 0.2$ & $1.43 \pm 0.0$ & $0.89 \pm 0.5$ \\
\hline WAM20 & $2.07 \pm 0.2$ & $2.14 \pm 0.0$ & $1.50 \pm 0.6$ & $0 . .66 \pm 0.7$ \\
\hline
\end{tabular}


Festus et al./ Carpathian Journal of Food Science and Technology, Special Issue 2020, 12(5), 99-108

\begin{tabular}{|l|l|l|l|l|}
\hline WAM25 & $2.08 \pm 0.7$ & $2.16 \pm 0.9$ & $1.53 \pm 0.2$ & $0.64 \pm 0.6$ \\
\hline PIN10 & $2.10 \pm 0.0$ & $2.16 \pm 0.4$ & $1.50 \pm 0.5$ & $0.59 \pm 0.1$ \\
\hline PIN40 & $2.05 \pm 0.1$ & $2.11 \pm 0.0$ & $1.45 \pm 0.1$ & $0.50 \pm 0.4$ \\
\hline PIN32 & $217 \pm 0.8$ & $2.39 \pm 0.1$ & $1.89 \pm 0.0$ & $1.18 \pm 0.5$ \\
\hline PIN12 & $2.11 \pm 0.6$ & $2.28 \pm 0.7$ & $1.80 \pm 0.2$ & $1.00 \pm 0.8$ \\
\hline CAS15 & $2.06 \pm 0.6$ & $2.18 \pm 0.5$ & $1.60 \pm 0.1$ & $0.85 \pm 0.3$ \\
\hline CAS36 & $2.08 \pm 0.2$ & $2.20 \pm 0.1$ & $1.64 \pm 0.9$ & $0.93 \pm 0.7$ \\
\hline CAS3 & $2.10 \pm 0.1$ & $2.16 \pm 0.0$ & $1.55 \pm 0.3$ & $0.79 \pm 0.1$ \\
\hline
\end{tabular}

All previously reported observations on sugar tolerance are in agreement with the findings in this work. The ability of the yeast isolate to tolerate sugar concentration is due to the possession of osmotic stress resistant cells caused by dehydration (Homann,2003; GomarAlba et al.,.2015) They are frequently isolated from high-sugary substrates such as fruits, honey, and jam. (Patruscus et al.,.2009; Alakeji et al. (2015). Ogunremi et al. (2015) and Sulieman et al. (2015) confirmed their ability to cause food spoilage. Examples of some sugar tolerant yeast spp are Candida bombicola; Tolulaspora delbrueckii; Zygosaccharomyces bailli; Zygosaccharomyces rouxii and it has been reported that they grow in medium containing $40-70 \%(\mathrm{w} / \mathrm{w})$ sugar .Sugar tolerant yeasts are osmophillic in nature, desirable and are good candidates for production of polyalcohols thus showing potential for industrial application (Deak, 2006; Turker, 2014) Their sugar-tolerant attribute is exploited in the processing of functional foods (health drinks, enzyme drinks, and fermented vegetable extract) which possess various health-regulating functions. Their immense contribution to the unique functions of these novel foods is partly due to the possession of antibacterial activity (Boirivant and Stober,2007)

The result of growth of yeast isolates at different $\mathrm{pH}$ is shown in Table 6. It was observed that all the yeast species grew within the $\mathrm{pH}$ range of 2 to 8 showing different levels of growth with optimum growth at $\mathrm{pH} 6$ after which no growth was observed. PIN32 (Saccharomyces cerevisiae 4) and WAM8 (Saccharomyces cerevisiae 1) recorded the highest growth of 1.55 followed by WAM 20 (Saccharomyces cerevisiae 2) producing a growth of $1.47 \pm 0.3$ and least $(0.94 \pm 0.1)$ was recorded by CAS36 (Debaromyces polymorphus). Minimum growths were recorded at extreme $\mathrm{pH}(2$ and 8$)$ and all the yeast isolates showed no growth at $\mathrm{pH}$. The growth pattern demonstrated by yeast spp. with $\mathrm{pH}$ variation had previously been reported by Narendramata and Power (2005) and Deak,(2006). Alakeji et al.(2015) reported that mould and yeasts could tolerate range $\mathrm{pH}$ between 2-8 and their ability to tolerate low $\mathrm{pH}$ (acidic $\mathrm{pH}$ ) serves as a strategy to eliminate spoilage microbes and create a conducive environment for growth of desirable microorganisms (Boirivant and Stober,2007).

Table 6. Tolerance of yeasts isolate to different $\mathrm{pH}$

\begin{tabular}{|l|c|l|l|c|}
\hline Isolate code & $\mathbf{2}$ & $\mathbf{4}$ & $\mathbf{6}$ & $\mathbf{8}$ \\
\hline WAM8 & $0.36 \pm 0.2$ & $1.12 \pm 0.1$ & $1.55 \pm 0.5$ & $0.00 \pm 0.0$ \\
\hline WAM11 & $0.34 \pm 0.1$ & $1.27 \pm 0 . .6$ & $1.29 \pm 0.1$ & $0.00 \pm 0.0$ \\
\hline WAM20 & $0.47 \pm 0,1$ & $1.23 \pm 0.2$ & $1.47 \pm 0.3$ & $0.00 \pm 0.0$ \\
\hline WAM25 & $0.18 \pm 0.0$ & $1.01 \pm 0.0$ & $1.18 \pm 0.2$ & $0.03 \pm 0.0$ \\
\hline PIN10 & $0.34 \pm 0.0$ & $1.11 \pm 0.3$ & $1.32 \pm 0.0$ & $0.00 \pm 0.0$ \\
\hline PIN40 & $0.22 \pm 0.1$ & $0.94 \pm 0.0$ & $1.25 \pm 0.7$ & $0.00 \pm 0.0$ \\
\hline PIN32 & $0.21 \pm 0.0$ & $1.27 \pm 0.1$ & $1.55 \pm 0.1$ & $0.00 \pm 0.0$ \\
\hline PIN12 & $0.26 \pm 0.3$ & $1.09 \pm 0.5$ & $1.28 \pm 0.6$ & $0.00 \pm 0.0$ \\
\hline
\end{tabular}




\begin{tabular}{|l|l|l|l|l|}
\hline CAS15 & $0.21 \pm 0.2$ & $0.71 \pm 0.2$ & $0.94 \pm 0.4$ & $0.00 \pm 0.0$ \\
\hline CAS36 & $0.19 \pm 0.1$ & $1.04 \pm 0.3$ & $1.31 \pm 0.0$ & $0.09 \pm 0.0$ \\
\hline CAS3 & $0.17 \pm 0.0$ & $1.13 \pm 0.7$ & $1.40 \pm 0.2$ & $0.00 \pm 0.0$ \\
\hline
\end{tabular}

Table 7 represents the growth of the yeast isolates. at different temperatures The optimum temperature for growth of all the yeast isolates was $30^{\circ} \mathrm{C}$ but a sharp decline in growth was observed as the temperature reached $40^{\circ} \mathrm{C}$ and no growth was recorded at $45^{\circ} \mathrm{C}$. The isolates grew optimally within a temperature range of $30-35^{\circ} \mathrm{C}$ with PIN32 (Saccharomyces cerevisiae Saccharomyces4) producing the highest growth of $2.50 \pm 0.6$ followed by WAM8 (Saccharomyces cerevisiae 1) with a growth of $2.45 \pm 0.1$ and the least $2.15 \pm 0.3$ was recorded by CAS 36 (Debaromyces polymorphus).The growth pattern of yeast isolates obtained at different temperatures in this study is in consonance with the finding of Caspeta et.al.(2016) and Taluhder et al.(2016) that reported the activity of yeasts within a temperature range of $20-30^{\circ} \mathrm{C}$ The inability of the yeast species to grow at extreme temperature of $45^{\circ} \mathrm{C}$ is due to the high stress associated with this temperature (Sathees et al., 2011;Choudhary,2016). The growth of yeast spp. within a temperature range of $20^{\circ} \mathrm{C}-40^{\circ} \mathrm{C}$ confirmed the vast difference in their thermo stability and maximum growth at $30^{\circ} \mathrm{C}$ makes the yeast species suitable in fermentation process as this temperature corresponds with the temperature of fermentation which usually takes place within a temperature range of 20 $30^{\circ} \mathrm{C}$ (Keller, 2010).

Table 7. Tolerance of yeasts isolate to different temperatures

\begin{tabular}{|l|l|l|l|l|l|l|}
\hline Isolate code & $\mathbf{2 0}^{\mathbf{}} \mathbf{C}$ & $\mathbf{2 5}^{\mathbf{}} \mathbf{C}$ & $\mathbf{3 0}^{\mathbf{}} \mathbf{C}$ & $\mathbf{3 5}^{\mathbf{C}} \mathbf{C}$ & $\mathbf{4 0}^{\mathbf{C}} \mathbf{C}$ & $\mathbf{4 5}^{\mathbf{}} \mathbf{C}$ \\
\hline WAM 8 & $1.05 \pm 0.4$ & $1.60 \pm 0.6$ & $2.45 \pm 0.1$ & $2.34 \pm 0.2$ & $0.50 \pm 0.1$ & $0.00 \pm 0.0$ \\
\hline WAM 11 & $1.17 \pm 0.9$ & $1.55 \pm 0.3$ & $2.29 \pm 0.6$ & $2.19 \pm 0.3$ & $0.41 \pm 0.2$ & $0.00 \pm 0.0$ \\
\hline WAM 20 & $1.21 \pm 0.5$ & $1.59 \pm 0.5$ & $2.21 \pm 0.8$ & $2.13 \pm 0.2$ & $0.33 \pm 0.0$ & $0.00 \pm 0.0$ \\
\hline WAM 25 & $1.12 \pm 0.4$ & $1.64 \pm 0.1$ & $2.34 \pm 0.0$ & $2.20 \pm 0.1$ & $0.36 \pm 0.1$ & $0.00 \pm 0.0$ \\
\hline PIN 10 & $1.38 \pm 0.2$ & $1.73 \pm 0.3$ & $2.16 \pm 0.1$ & $2.08 \pm 0.0$ & $0.46 \pm 0.1$ & $0.00 \pm 0.0$ \\
\hline PIN 40 & $1.24 \pm 0.2$ & $1.47 \pm 0.0$ & $2.18 \pm 0.2$ & $2.05 \pm 0.5$ & $0.46 \pm 0.3$ & $0.00 \pm 0.0$ \\
\hline PIN 32 & $1.21 \pm 0.5$ & $1.66 \pm 0.2$ & $2.50 \pm 0.6$ & $2.32 \pm 0.2$ & $0.78 \pm 0.2$ & $0.00 \pm 0.0$ \\
\hline PIN 12 & $1.16 \pm 0.1$ & $1.59 \pm 0.5$ & $2.11 \pm 0.1$ & $2.04 \pm 0.3$ & $0.14 \pm 0.1$ & $0.00 \pm 0.0$ \\
\hline CAS 15 & $0.79 \pm 0.4$ & $1.46 \pm 0.7$ & $2.16 \pm 0.2$ & $2.11 \pm 0.3$ & $0.06 \pm 0.2$ & $0.00 \pm 0.0$ \\
\hline CAS 36 & $1.14 \pm 0.0$ & $1.58 \pm 0.2$ & $2.15 \pm 0.3$ & $2.10 \pm 0.8$ & $0.09 \pm 0.0$ & $0.00 \pm 0.0$ \\
\hline CAS 3 & $1.29 \pm 0.3$ & $1.62 \pm 0.0$ & $2.19 \pm 0.1$ & $2 . .08 \pm 0.2$ & $0.09 \pm 0.1$ & $0.00 \pm 0.0$ \\
\hline
\end{tabular}

Table 8 shows the result of the identification process of the eleven yeast isolates. They were identified as Saccharomyces cerevesiae (5),
Saccharomyces kluyveri (1), Pichia farinose (1), Kloeckera japonica(1), Pichia ohmeri (1) Debaryomyces polymorphus(1), Candida tropicalis (1)and Candida kefyr.(1). 
Table 8. Identification result of the Isolates

\begin{tabular}{|l|l|c|l|}
\hline Isolate code & Source & Number of isolate & Identity \\
\hline WAM 8 & Water melon & 1 & Saccharomyces cerevisiae 1 \\
\hline WAM 11 & Water melon & 1 & Pichia farinose \\
\hline WAM 20 & Water melon & 1 & Saccharomyces cerevisiae 2 \\
\hline WAM 25 & Water melon & 1 & Kloeckera japonica \\
\hline PIN 10 & Pineapple juice & 1 & Saccharomyces kluyverii \\
\hline PIN 40 & Pineapple juice & 1 & Saccharomyces cerevisiae 3 \\
\hline PIN 32 & Pineapple juice & 1 & Saccharomyces cerevisiae 4 \\
\hline PIN 12 & Pineapple juice & 1 & Pichia ohmeri \\
\hline CAS 15 & Cashew juice & 1 & Saccharomyces cerevisiae 5 \\
\hline CAS 36 & Cashew juice & 1 & Debaromyces polymorphus \\
\hline CAS 3 & Cashew juice & 1 & Candida kefyr \\
\hline
\end{tabular}

Isolation and identification of yeast from fruits, fermented foods and beverages had earlier been reported by Maragatham and Panneerselvam (2011), Somdatta et. al. (2011) and Zerihun (2016). The involvement of yeasts in different types of indigenous fermented foods and fruits has been documented ( Ogunremi et al.,2015). Their existence in fermented foods and fruits is due to their sugar loving characteristics and their fermentative ability (Djelal et al.,2017)

\section{Conclusions}

Considering the result obtained in this study isolates PIN32 (Saccharomyces cerevisiae 4) and WAM 8 (Saccharomyces cerevisiae 1) may be selected as potential starter cultures for the production of pineapple wine.

\section{References}

Akinjogunla, O.J., A.O. Ajayi, N.O. Ekeh (2014). Virulence factors and antibiotic resistant Staphylococcus spp from the anteriornares of apparently healthy undergraduate students in uyo. American Journal of Research Communication, 2(11), 158-180.

Akubor, P.J., Obio S.O., Nwadomere, K.A., and Obiomah, E. (2003) Production and quality evaluation of banana wine. Journal of Plant Food Human, Nutrition, 58, 1-6.
Akabanda, F., Owusu-Kwarteng, J., TanoDebrah, K., Glover, R.L.K., Nielsen, D.S. and Jespersen, L. 2013. Taxonomic and molecular characterization of lactic acid bacteria and yeasts in Nunu, a Ghanaian fermented milk product. Food Microbiology, 3, 277-283.

Alakeji, T.P., K. Banwo, O.R. Ogunremi, A.I. Sanni (2015). Functional properties of yeasts isolated from some Nigerian traditional fermented foods. Journal of microbiology biotechnology and food science, 4 (5), 437-44

Albergaria,H.,Arneborg,N.(2016).Dominance of Saccharomyces cerevisiae alcohol fermentation process ;role of physiological fitness and microbial interactions Applied Microbiology and Biotechnology, 100, 2035-2046

Alexandre, H., Costello, P. J., Remize F., Guzzo J., and Guilloux-Benatier M. (2004). Interactions in wine: current knowledge and perspectives. International Journal of Food Microbiology, 93, (2), 141-154.

Alonso del-Real, J., Lairon-Peris,M.,Barrio,E., Querol,A.(2017) Effect of temperature on the prevalence of Saccharomyces noncerevisiae species against Saccharomyces cerevisiae wine strains in wine in fermentation competition, physiological fitness and influence in final wine 
,composition, Frontiers in microbiology 8, 150-3

Alloysius, C.O., Ositadinma C.U., Amadike E.U., and Chukwuma S.E. (2015). Production of mixed fruit (pawpaw,banana and water melon)using Saccharomyces cerevisiae isolated from palm wine. African Journal of Food Science, 10, 1-11.

Balakmar,S and Arasaknam,V (2012) Osmotolerant and ethanol- tolerance of Saccharomyces cerevisiae S1, Brazilian Journal of Microbiology, Vol. 43.

Blackwell, M., Suh, S.O., McHigh, J.V., and Pollock, D.D. (2005). The bettle gut: a hyperdiverse source of novel yeasts". Mycological Research, 109 (3), 261-265.

Bolarin, F.M., Olotu, F.B., and Onyemezie, U.C - (2016.) Fruit; it prospects for juice and wine production. European Journal of Educational and Development Psychology, 4,25-32.

Boirivant, M. W. Strober (2007). The mechanism of action of probiotics. Current Opinion in Gastroenterology 23, 679-692.

Caspeta,L., Chea,Y and Neilsen,J.(2016) Thermotolerant yeast selected by adaptive evolution express heat stress response at 300 C Scientific report, 6, 27003, doi:1038/srep27003

Chandrasena G., Keerthipala A.P., and Walker G.M. (2006). Isolation and Characterization of Sri Lankan Yeast Germplasm and ion. Journal Institute Brewing, 112, 302-307.

Choudhary,J., Singh, S., Nain,L.(2016) Thermotolerant fermenting yeasts for simultaneous saccharification fermentation of lignocellulosic biomass .Electronic journal of biotechnology, 21(c);82-92.

COVECA (2002). Comisión Veracruzana de Comercialización Agropecuaria. Gobieno del Estado de Veracruz, Mexico. Thomas Edison

Dele Cruz, J and Torres, O.M.(2012) Gelatin hydrolysis test protocol, American Society for Microbiology. 2/29/20
Dash, P.K.,Mistra M., Patonaik, S.C., Gwain M.R., Thatoi, H.N. (2015). Characterization, identification and comparative evaluation of bioethanol tolerance and production capacity of isolated yeast strains from fermented date palm sap (toddy). Malaysian journal of Microbiology, 11(7), 223-230

Deak, T. 2006. Environmental factors influencing yeasts. Biodiversity and Ecophysiology of Yeasts (The Yeast Handbook series). Eds. G., Péter and C., Rosa. Berlin: Springer. 155-174.

Dickinson,J.R., and Kruckkeberg,A.l.(2006) carbohydrate metabolism. Yeast in food and beverages, 215-242.

Djelal,H., $\quad$ Chniti,S.,JEmni,M.,Well,A., Sayed,W., and Amrane,A(2017) Identification of Saccharomyces cerevisiae strains isolated from dates (Phoenix dactylifera L) for enhancing very high gravity ethanol production .Environmental science pollution research, 24, 9886-9894

Eze, V.C., Eleke, O.I., Omeh, Y.S. (2011). Microbiological and nutritional qualities of burukutu sold in mammy market Abkpa, Enugu State, Nigeria. American Journal of Food and Nutrition, 1(3), 141-146.

Guimaraes, L. H., Terenzi H. F., de Moraes M.T. and Jorge J. A (2007). Production and characterization of thermo stable extracellular $\beta$ - fructofuranosidase produced by Aspergillus ochraceus with agro industrial residues as carbon sources. Journal of Enzyme and Microbial Tecnology, 42(1),52-57.

Gomar-Alba, M.A.,Angeles-Morcillo, P.,Merceclli ,D.O.(2015) Response of cells to high glucose involves molecular and physiological difference when compared to other osmostress conditions FEMS Yeast Res 15(5):fov039

Hohmann, S(2002), Osmotic stress signaling and osmoadaptation in yeasts, Microbiology and molecular biology review, 66(2), 300372 
Idise, O.E.(2012) Studies of wine production from pineapple (Ananas comosus) International journal od biotechnology and molecular biology research, vol 3(1), 1-7.

Islam et al (2015) Isolation, characterization and Process optimization of ethanol producing thermotolerant potential yeast strain from sugar industrial waste, International journal of life science and review, 6, 227-237.

Magnuson J.K., Lasure L.L. (2004) Organic Acid Production by Filamentous Fungi. In: Tkacz J.S., Lange L. (eds) Advances in Fungal Biotechnology for Industry, Agriculture, and Medicine. Springer, Boston, MA. https://doi.org/10.1007/978-14419-8859-1 12

Keller, M. (2010).The science of grape vines agronomy and physiology. San Deigo: Academic press, (Chapter 2).

Kaur, N., Sharma, A.D. (2005). Production optimization and characterization of extracellular invertase by actinomycete strain. Journal Science Indian Research, 64, 515-519.

Lea, A.G., Piggott, J.R. (2003). (Eds.). Fermented beverage production (2nded). New York, Kluwel academic publisher, 423.

Mahesh P., Ravikiran B., and Ulhas P. (2012). Invertase production from Aspergillus spp M1 isolated from Honeycomb. International Journal of Applied Bioresearch,4,1-5.

Maragatham, C., and Panneerselvam, A. (2011). Isolation, identification and characterization of wine yeast from rotten papaya fruits for wine production. Advances in Applied Science Research, 2 (2), 93-98.

Matapathi, S.S., Patil, A.B., Jones, P., Nirmalnat, T, and Savalagi, V.V. (2004). Isolation and Screening of Efficient Yeast Strains for Wine Making Karnataka. Journal Agricultural Science, 17(4), 736-740.

Mobini, D.M., Nahvi, I.H., Zarkesh, E.K., Ghaedi, M., Tavassoli, R., and Akada, R (2008). Isolation of a novel mutant strain of Saccharomyces cerevisiae by an ethyl methane sulfonate- induced mutagenesis approach as a high producer of bioethanol. Journal of Bioscience Bioengineering, 105, (4), 403-408.

Moneke, A.N., Okelo, B.N., Nweke A.I., Ezeogwu L.I., Ire, F.S. (2008). Selection and characterization of high ethanol tolerance Saccharomyces cerevisiae yeast from orchard soil. African journal of biotechnology, 7 (24),4567-4575.

Morandi, L.A., Maffia, E.S.G., Mizubuti, A.C., Alfanas, J.G., Barbosa, C.D., and Cruz, P (2006). Relationship of microclimatic variables to colonization of rose debris by Botrytis cinerea and the biocontrol agent Clonostachys rosea. Biocontrol Science and Technology. 16, 619-630

Narendramata, N., Wu V., and Power R (2004). Relationship between $\mathrm{pH}$ and medium dissolved in terms of growth and metabolism of Lactobacilli and Saccharomyces cerevisiae during ethanol production. Applied Environmental Microbiology, 71, 2239-2243.

Ogunremi, O.R., A.I.Sanni, R. Agrawal (2015). Probiotic potentials of yeasts isolated from some cereal-based Nigerian traditional fermented food products. Journal of Applied Microbiology, 119, 797-808.

Okafor,N.(2007) Microbiolgy and biochemistry of oil palm wine, Advances in Applied Microbiology. 24, 273-285.

Osho, A. (2005). Ethanol and sugar tolerance of wine yeasts isolated from fermenting apple juice. Africa Journal of Biotechnology, 4 (7), 660-662.

Patruscus et al.(2009) Isolation and identification of yeast strains from sugar cane molasses, dates, and figs for ethanol production under conditions stimulating algal hydrolysate Brazilian journal of chem. Eng. Vol 36 No1 Sao Paulo.

Pretoritus,V. (2000) Tailoring wine yeast for new millennium. Novel approaches to the ancient art of wine making . Yeast 16 (8), 675-729 
Sathees, V.K., Shankar, T., and Anandapandian, K.T. (2011). Characterization of alcohol resistant yeast Saccharomyces cerevisiae isolated from Toddy. International Research Journal of Microbiology, 2(10), 399-405.

Shafiq, S., Sikander, A., and Haq, I. (2002). Effect of different mineral nutrients on invertase production by Saccharomyces cerevisiae GCB-K5. Biotechnology, 1, 4044.

Shankar, T., Thangamathi, P., Rama, R. and Sivakumar, T. (2013). Optimization of invertase production using Saccharomyces cerevisiae MK under varying cultural conditions. International Journal of Biochemistry and Biophysics. 1(3), 47-56. DOI: 10.13189/ijbb.2013.010301.

Shetty,P.,Udupi,V.,Madanthyar,B.,Ramasubra manian,S.,Maliekal,S.,Ramachandran,L.D.( 2019), Pineapple: potential source of proteolytic enzyme for degumming of raw silk MCDC.MS.ID 000585 (4), 2.

Sivakumar T. I., Ravikumar, M., Prakash, M., and Shanmugaraju, V. (2013). Production of extracelluar invertase from Saccharomyces cerevisiae strain isolated from grapes. International Journal of Current Research and Academic Review, 1, 72-83.

Silveira, M.C., Oliveira, E.M., Carvajal, E., and Bon, E.P. (2000). Nitrogen regulation of Saccharomyces cerevisiae invertase. Role of the URE2 gene. Applied Biochemistry Biotechnology, 84, 247-254.

Snopeh,1.,Mlcek,J., Sochorova, L.,Baron, M.,Hlavacova, I.,Juricova, T.,Kizek,R.,Sediackova,E., and Sochor, J.(2019.) contribution of red wine consumption to human health problems Molecules, 23(7), 1684.

Somdatta, C., Barnita, G., and Rinarani, R (2011). isolation and characterization of local yeast strains from waste fruit juices, jaggery and dahi samples. International Journal Chemical Science. 9(2), 647-656.
Sulieman, A.E., Esra A.M. and Abdelgadir, W.S. 2015. Isolation and Identification of Yeasts from the Different Stages of Hulumur Fermentation. Journal of Microbiology Research, 5(2), 71-76.

Robinson, J.(2006)The oxford companion to wine 3rd.Ed.oxford university press pp.268780.

Sun,G.M., hang, M., and Soler, A. (2016) In book, Nutritional composition of fruits cultivars . Academic press Editions Simmonds M.S.Jpreed VIR pp 609-637.

Talekar, S., Ghodake V., Kate, A., Samant N., Kumar C., and Gadagkar, S. (2010). Australian Preparation and Characterization of Cross-linked Enzyme Aggregates of Saccharomyces Cerevisiae Invertase. Journal of Basic and Applied Sciences .4 (10), 4760-4765.

Taluhder,A.,Easmim,F.,Mahmud,A.S.,Yamand, M.(2016), Thermotolerant yeast capable of producing bioethanol: isolation from natural fermented sources, identification and characterization . vol.30 issue 6, 1106-1114

Tamang, J.P., K. Watanabe. W.H. Holzapfel (2016). Review: Diversity of Microorganisms in Global Fermented Foods and Beverages. Frontiers in Microbiology, 7, 377 .

Thammasttirong,S.N.,Thirasahtana,T.,Thamma sttirong,A et al..(2013) Improvement of ethanol production by ethanol -tolerant Saccharomycees cerevisiae UVNR 56 SpringerPlus, 2,583-600.

Techaparin,A., Thanonkeo,P.,Klanrit,P.(2017). High-temperature ethanol production using thermotolerant yeast newly isolated from Greater Mekong Subregion, Brazilian Journal of Microbiology,48(3),461-475

Tikka,C.,Osuru,H.P.,Arthur,N., Ragbhavulu, P.C.V.(2013)Isolation and characterization of ethanol tolerant yeast stains Bioinformation, 9(8), 421-425.

Türker, M. 2014. Yeast Biotechnology: Diversity and Applications. Advances in Science and Industrial Productions of 
Baker's Yeast. 27th VH Yeast Conference, Istanbul.

Zerihun, T. (2016). Isolation, identification and characterization of ethanol tolerant yeast species from fruits for production of bioethanol. International Journal of Current Trends in Pharmacobiology and Medical Sciences, 2, 2456-2432 